\title{
Asset Modelling on Cost Replacement towards Transparency of Building Replacement
}

\author{
Mohamad Adzizulrohim Bin Abd Malek ${ }^{1, a}$, Azlan Shah Bin Ali ${ }^{2}$ and Mohamad Rizal Bin Baharum ${ }^{3}$ \\ ${ }^{1}$ Department of Built Environment, University of Malaya, Malaysia \\ ${ }^{2}$ Department of Built Environment, University of Malaya, Malaysia \\ ${ }^{3}$ Department of Built Environment, University of Malaya, Malaysia
}

\begin{abstract}
This paper presents development of a model to be used to select the best option for building replacement in public ownership such as public library, stadium, hospital and school buildings. Buildings life cycle management should be transparent and cost efficient. Hence, decisions taken during the life cycle of the buildings should be based on clear justification. One of the major issues in facility planning is to determine whether to rebuild or restore the existing facility. In fact, for government assets, they have to be economically managed by knowing the holding cost, so that it is viable to be retained in long run. The objectives of this paper were to establish relationship between replacement cost and cost decision making factors through the development of replacement cost model towards an economic efficiency for government buildings. Three stages of process were involved in this study. They are, stage 1, which explain on the significance factors of Cost Decision Making (CDM) and Replacement Cost (RC). It followed by exploration of the relationship between $\mathrm{CDM}$ and RC in Stage 2. Finally, the development of replacement cost model that expected to increase economic efficiency and transparency of building replacement. The results expected to provide a raw evidences to support a concept that refurbishment of existing building would be more benefit than replacement to the new ones. It is also expected that the results could be used by organizations especially for the decision makers as a guideline or tool to make a wise decision in building replacement related activities.
\end{abstract}

\section{Introduction}

It is well understood that the subject of building replacement is relatively new and considered juvenile in Malaysia. There are a few researchers that have been carried out focusing on the scope and the element of building replacement. By the way, very less attention has been given on building replacement decision making and it is very rare to see research carried out on the subject of replacement cost of building. As for the federal government, there is no standard format or guide line to be called standard operating procedure to be followed as a guide or a blueprint to the entire public client in terms of building refurbishment. The determination of the cost for refurbishment work in government-own buildings is the federal government or the state government building has always been a headache and conflict between the contractor and client. Worsening the scenario, it is always a problem and it is usually a very hard task to determine the exact cost of refurbishment works such as repairs, replacement or internal maintenance works and estimated cost usually go haywire and far from the actual cost. Unfortunately, there is no uniformity in the procurement procedure or standard contract regulation being used. In the public sector, it is known that among the biggest obstacle is the 'resistance to change'. (N.Mohd Noor, 2011).

This study will also review and identify the public sector practice in the aspect of building replacement management and their relation in cost decision determination. It is hope to lead to a better understanding of the issues related to the costs 
matters in government owned building maintenance and asset management. The aim of this paper is to promote innovative model that will become a framework or guideline as to improve and as an added value to the existing procedure. This model will also consider some adaptation from the existing model that has been implemented by other countries. These have been proven to be effective and successful in its implementation. However it should taking into account our local culture and environment. It is hope that this cost decision model will benefit the largest owner that is public authorities such as The Ministry of Work and Public Work Department as the biggest agency that manage the government buildings.

Table 1: The Distribution of Pre War Urban Building in Malaysia

\begin{tabular}{|c|c|c|c|c|c|}
\hline No & States & No of Historical Buildings & No & States & $\begin{array}{c}\text { No of Historical } \\
\text { Buildings }\end{array}$ \\
\hline 1 & Penang & 5057 & 8 & Sarawak & 1010 \\
\hline 2 & Perak & 3351 & 9 & Negeri Sembilan & 999 \\
\hline 3 & Johor & 2323 & 10 & Pahang & 831 \\
\hline 4 & Malacca & 2177 & 11 & Terengganu & 420 \\
\hline 5 & Kuala Lumpur & 1763 & 12 & Kelantan & 373 \\
\hline 6 & Kedah & 1282 & 13 & Perlis & 25 \\
\hline 7 & Selangor & 1166 & & Sabah & 10 \\
\hline
\end{tabular}

For introduction, refer to Table 1 as example, there are still many historical building and old building in Malaysia. Since the building boom of the 1970s, many of Malaysia's historic buildings have been demolished. Recent large scale urban development continues to threaten pre-war buildings, while other historic buildings are simply deteriorating due to age, neglect and high cost of maintenance. Fee (1998) expressed that to lose these buildings, however is effectively to obliterate historical memories, and there is now increasing pressure from

While most of the buildings surveyed were new developments, several were refurbishments of existing buildings. With the growing recognition of the important role that refurbishment may play in improving the performance of the existing building stock, it was seen as important, given the constraints inherent in refurbishing an existing building, to compare their performance with the new ones. The key conclusion is that extensive refurbishments, and even fit outs within the constraints of an existing shell, are quite capable of equalling and even surpassing the performance of completely new designs from the point of view of the building users (George Baird, 2014). Building life cycle management should be transparent and cost efficient. Hence, decision making taken during the life cycle of the building should be based on clear justification. various segments of the community to conserve the nation's historical heritage. As we all known that conservation is the action taken to prevent decay, embracing all acts that prolong the life of cultural and natural heritage. Building conservation according to (Fielden,2000; Insall,1972) relates specifically to the process of repair, maintenance and restoration of historic buildings which aim to prolong a building's life and function.

\section{Literature Review}

\subsection{Decision Making}

Many managerial researches in the past several decades, especially in the early 80 's, have investigated and written about managerial decision making from a variety of dimensions and perpsectives (e.g. Argyris, 1976; Cohen et al., 1972; Hickson et al.,1986; Mintzberg et al.,1976; Simon,1957; Werhrich \& Koontz,1993; Kim\&Mauborgne, 1998). In spite of this ongoing attention, the subject of decision making is still in contradictory and controversial phase with theoretical dilemmas. Harrison (1999) believed that part of the problem is derived from the multidisciplinary nature of the decision making (e.g psychology, economics, 
politics, sociology and mathematics which all contribute their own perspectives). The problem can be more complicated by differentiating decision maker into individual, group, multi-group or organizational (Kriger \& Barnes, 1992). The preceding discussion illustrates three important themes in managing an organization: (1) the link that exists between the success of an organization and the quality of its managerial functions, (2) the link that exists between success of the managerial functions and managerial decision-making outcomes, and (3) the third theme is related to the first two, attempt to link managerial decisions outcomes to knowledge and ability of managers in making a decision. This theory represent as Figure 1 below:

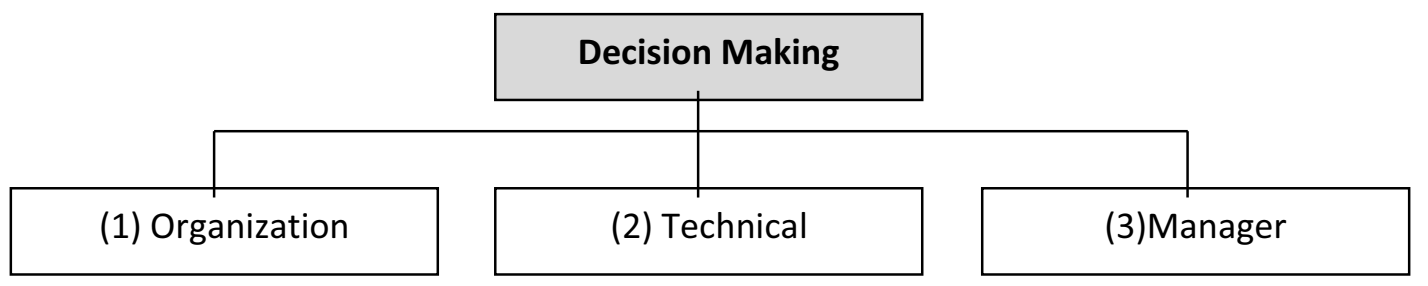

Figure 1: Decision Making Factors

\subsection{Sustainable Asset Management}

Sustainable asset management crystallized the concept of 'cradle to the grave' into existence. It basically puts forth the consideration for maintenance right from the design stage all the way to the operation of the building, as well as making it ready for adaptive re-use. Based on Figure 2, achieving sustainable asset management basically deals with the business process, human resources and information technology system. In whatever task we perform, the business process must be there and in ensuring it is well implemented, we need various levels and competency of team members. It is not a one man show. As we are now living in the millennium era, Information Technology (IT) is in every business process. Data needs to be converted into information and IT makes this happen within a click. (Che Ani,Badaruzzaman, 2010)

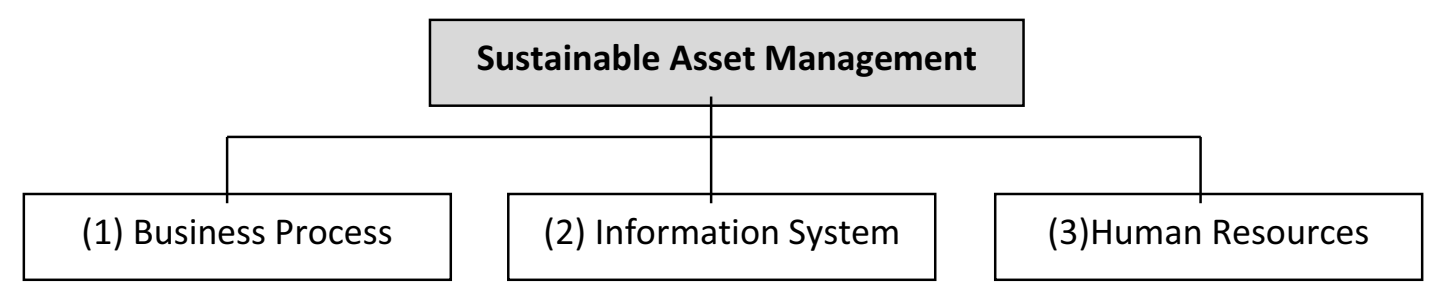

Figure 2: Sustainable Asset Management Factors

From these Figure 1 and Figure 2, we can conclude that decisions making for asset replacement are based on 3 significant factor such as of human factor, technical factor and organization factor. Generally, the cost decision making are based on manager experience, building condition and availability of

\section{Cost Decision Making Factors}

\subsection{Human Factor}

Having identified the best practices in business process, we need human capital in executing the idea. Human are the best machines and super power funding while the replacement cost are based on budget determination, mode of government procurement and existing practices of replacement. However, the detail explanation of these three key areas is represented in the next topic.

computer in ensuring best practices are put in place. Therefore, we need team members with various technical knowledge and competence. It ranges from the design team to the building management team. Competency is best represented from the outcome of an academic programme developed by Malaysian Qualification Agency (MQA). In our context, the 
professional services involve the professions of Architect, Engineer, Quantity Surveyor, Valuation Surveyor, Town Planner, Landscape Architect, Land Surveyor, Interior Architecture and Building Surveyor. All these professional services contribute to the different factor in cost decision making. (Che Ani,Badaruzzaman, 2010) The following are details of human factors that contribute to the cost decision making:

\subsubsection{Past Experiences or Manager Experience}

Past experience can impact future decision making. Juliusson, Karlsson and Garling (2005) indicated past decisions influence the decisions people make in the future. It stands to reason that when something positive results from decision, people are more likely to decide in a similar way, given a similar situation.

\subsubsection{Age \& Individual Differences}

Some individual differences may also influence decision making. Research has indicated that age, socioeconomic status, and cognitive abilities influences decision making (De Bruin, Parker \& Fischoff, 2007; Finucane, Mertz, Slovic \&Schmidt, 2005). Finucace et. al established a significant different in decision making across age; that is; as cognitive functions decline as a result of age, decision making performance may decline as well. In addition, older people may be more overconfident regarding their ability to make decisions, which inhibits their ability to apply strategies (De Bruin et al, 2007). Finally, with respect to age, there is evidence to support the notion that older adults prefer fewer choices than younger adults. (Reed, Mikels \& Simon, 2008)

\subsubsection{Belief in Personal Relevance}

When people belief what they decide matters, they are more likely to make a decision. Acevedo and Krueger (2004) examined individuals' voting pattern, and concluded that people will vote more readily when they believe their opinion is indicative of the attitude of the general population as well as when they have a regard for their own importance in the outcomes. People vote when they believe their vote counts. Acevedo and Krueger pointed out this voting phenomenon is ironic; when more people vote, the individual votes countless in electoral math.

\subsubsection{Escalation of Commitment}

In addition to past experiences and cognitive biases, decision making may be influenced by an escalation of commitment and sunk outcomes, which are unrecoverable costs. Juliusson, Karlsson and Garling (2005) concluded people make decisions based on an irrational escalation of commitment, that is, individuals invest larger amounts of time, money and effort into a decision to which they feel responsible for the sunk costs, time, money, and effort spent on a project. As a results, decision making may at times be influenced by how far in the hole the individual feels he or she is (Juliusson et al, 2005)

\subsubsection{Client Request}

Client refers to the owner of a building. The client is the one who provides maintenance finance and project brief in the early stage of maintenance works. Quality of client's brief would influence the building performance. Boyle (2003) notes that the key successful of design is rests much with the clients besides others such as a good budget.

\subsubsection{Complaint Received Regarding Building Performance}

Inefficient maintenance works could invite complaints by the building users. Users are normally looking for a comfortable space in a building. This includes well functions of building equipment's, clean environment and safe. If buildings do not fulfil the user's needs, complaints with regards to maintenance performance would be made by the users. Therefore, in formulating decision with regards to maintenance cost, element of user's satisfaction is vital and need to take into consideration (Latef,2008; PWD, 2009)

\subsection{Technical Factor}

The asset management cycle covers planning until the disposal stage (or adaptive re use). In the global arena, various theories and tools have been developed to support this idea. Among them are Building Performance Evaluation (BPE), Construction Operations Building Information Exchange (COBIE), Buildings Information Modelling (BIM) and Return on Investment (ROI). Others technical factor that contribute to the cost decision making are as follow:

\subsubsection{Existing Building Condition}

The existing conditions of buildings were assessed through several ways. One of the easiest methods is by using viral survey. The exterior of each building structure was viewed from the ground level and all important information would be documented and some areas of deterioration are noted through annotated sketches and plans. However, with recent new technology, detecting building defects would be 
more effective by implementing non-destructive test (Pitt, 1997; Lee and Scott,2009)

\subsubsection{Building Age}

Age of building provides important indication on level of maintenance service required. Lateef (2008) argues that one of the important elements that need to be considered in allocation of maintenance resources is building's age. In order to know the future image of building, building manager needs to offer right service so that the building has competitive advantage. Service given must meet expectation in response to time, delivery schedules and within the agreed performance indicator. In general, the older is building, the more attention and focus to special maintenance works need to be carried out.

\subsubsection{Performance Evaluation}

The best decision on whether to repair or replace can only be reached by evaluating the equipment in the broadest possible terms. For example, when considering whether to refurbish or replace a piece of pumping equipment, looking at the performance of associated motors and drives- their function, lifespan and cost of replacement- can help engineers to understand how the pump is performing in relation to the wider system. (2015, Conference of Pumping Best Practice, Telford)

\subsubsection{Energy Efficiency}

In order to fully incorporate sustainability into the decision making process, maintenance teams should evaluate the ongoing energy efficiency performance of an asset as well as the immediate environmental impact of repairing or replacing it. Then the environmental impact of their versus replacement can be measured by carrying out a calculation on the energy usage and the direct link between this, and the asset's carbon footprint, by focusing on reducing specific power.

The decision to repair or replace is not always a straightforward one. However, by working alongside an asset management and maintenance expert, it is possible for maintenance teams to make a fully informed decision. By taking a long term view, not only of the cost and performance benefits, but also the environmental effects of each approach, engineers are well placed to make the best decision in terms of cost, performance and sustainability. (2015, Conference of Pumping Best Practice, Telford)

\subsubsection{Information Technology (IT) System}

The myth about IT system is it will take care of every mechanistic task of asset management. We have to realize that IT is enabler for the whole structure of asset management, thus providing total solution for sustainable asset management. It is not that when we have superb IT system, everybody just stays back and become the observer. The IT system needs input to convert data into information, and this is found to be most lacking, leading to a white elephant project. As a rule of thumb, engage a business partner that provides total solution, rather than selling the software and gadgets. (Che Ani,Badaruzzaman, 2010)

\subsection{Organization Factor}

The prime objective of the Malaysian Government procurement is to support Government programmes by obtaining value for money through acquisition of works, supplies and services. To meet this objective close attention is given to price factors as well as non-price factors such as whole life cost, quality, quantity, timeliness, maintenance and warranty. The benefits or value from procurement should commensurate with the costs involved and that the best procurement is well and thoroughly evaluated, reasoned and justified. In this context, the Malaysian Government procurement is based on the following policies, principles, objective and procedures. Others organization factor are as follow:

\subsubsection{Availability of Funding}

A most trying constraint from the design point of view is the budget allocation. Boyle (2003) noted that most important factor contributing to successful maintenance work was a sufficient budget allocated for a project. The project fund must be sufficient to ensure the maintenance works could run smoothly.

\subsubsection{Government Policy}

Government assets have to be economically managed so it is vital to know the opportunity cost of holding them. The government wants to see the government heritage estate properly preserved and maintained through active use and reuse of the buildings. The government encourage the sustainable use of resources, and one aspect of that is to use and reuse older buildings wherever it sensible to do so. Government's planning policies are committed to maintaining the vitality of town centres where many specialized public listed properties are found rather than erecting new buildings on greenfield sites. (Anthony Andrew, 2000) 


\subsubsection{Safety \& Health Requirement}

Safety and health are command factors influenced in the decision making of maintenance works (Lee and Scott, 2009). This is because building maintenance works can lead a risk to maintenance personnel and building users. It is the responsibility of building stakeholders particularly the manager to ensure that health and safety assessment and safety work procedure are documented.

\subsubsection{Past Experience and Past Performance}

Analysis on Malaysia scenario in development of building and facilities aspect from First National Physical Plan (NPP) in 1956 until 10th Malaysia Plan in 2015. Performance and achievement of these plans as a guideline to the future planning.

\subsubsection{Informed Decision Making}

An invaluable part of any asset management programme is having a system in place to monitor and evaluate the ongoing performance of an asset. By measuring the efficiency of pumps and associated processes, engineers can understand the behaviour of piece of equipment and gauge when it is reaching the end of its lifetime or is at risk of failure. They can then make an informed decision in terms of repair or replacement and at the same time, include suitability of the asset and improve asset and system efficiency. (2015, Conference of Pumping Best Practice, Telford)

\section{Replacement Cost Factors}

Replacement cost definition is the amount it would cost to replace an asset at current prices. If the cost of replacing an asset in its current physical condition is lower than the cost of replacing the asset so as to obtain the level of services enjoyed when the asset was bought, then the asset is in poor condition and the firm would probably not want to replace it.

\subsection{Mode of Government Procurement}

\subsubsection{Direct Purchase}

Procurement of works up to the value of RM20,000 may be done through the issue of a Works Indent to a contractor who is registered with the Contractors Services Centre (PKK) and Construction Industry Development Board (CIDB) Malaysia.

\subsubsection{Quotation}

Procurement of works above the value of RM20,000 and up to RM500,000 is done through calling of quotations and the minimum number of quotations to be invited is five. All contractors wishing to take part in quotations must be registered with the PKK and CIDB.

\subsubsection{Tenders}

Procurement of works, supplies and services above the value of RM500,000 must be done through tender processes. All contractors intending to participate in local tenders must be registered with the government. International tenders will be invited for supplies and services if there are no locally produced supplies or services available. For specific works, if local contractors do not have the expertise and capability, tenders may be called on a joint venture basis between local and foreign contractors to encourage the transfer of technology. International tenders for works may only be called when local contractors do not have the expertise and capability, and a joint venture is not possible. (2015, Malaysia's Government Procurement Policies)

\subsection{Budget Determination}

The Prime Minister Department has given an instruction under the "Pekeliling Am Bil. 1 Tahun 2003, Arahan Penyelengaraan Bangunan Kerajaan di Putrajaya dated February 11th 2003," building maintenances must be efficiently and properly executed. The Government has also given instructions to all their agencies to carry out maintenances of all their building in the very early stage so that to reduce the cost of maintenance and to avoid risk of higher maintenance cost due to negligent through time.

\subsection{Existing Practices of Replacement Cost in Government}

The Malaysia industry reference point for asset management has to be the TAM Manual (Total Aset Management Manual), part of DPAK (Dasar Pengurusan Aset Kerajaan). Launched in April 2009 by former Prime Minister Y.A.B. Dato' Seri Abdullah $\mathrm{Hj}$. Ahmad Badawi, this document provides the key idea and direction for the whole life cycle of our assets. According to the manual, asset refer to moveable assets (aset alih), fixed assets (aset tidak alih), life asset (aset hidup) and intellectual property (harta intelek). With the wide coverage of assets, an asset management team is no longer focused on 
building only. It has to be integrated to achieve the aspiration of TAM Manual.

As for the federal government, there is no standard format to be called standard operating procedure to be followed as a guide or a blueprint to the entire public client in terms of cost analysis of building replacement. However, the existing practices of building replacements in government are as follow:

- TATACARA PENGURUSAN ASET TAK ALIH KERAJAAN 2012: Procedure that have been used by government as a guideline in asset disposal. The details of the procedure are in the Bab G: Pelupusan Aset.

- SYOR ROBOH: One of the procedure and guidelines that have been used by government in asset disposal.

- BCA (Building Condition Assessment): Condition assessments are technical inspections by competent assessors to evaluate the physical state of building elements and services and to assess the maintenance needs of the facility. Reliable and objective knowledge of the physical state of their buildings and the impacts on service delivery will enable department to develop appropriate strategies and actions for maintenance, major replacements, refurbishments and investment.

- BIM (Building Information Modelling): This model is an approach to design that uses intelligent 3D computer models to create, modify, share, and coordinate information throughout the design process. Many firms are using BIM to drive a more efficient design process.

- LCC Model (Life Cycle Costing): LCC model is an accounting structure containing terms and factors which enable estimation of an asset's component costs. A number of commercially available models can be used for LCC analysis. However, in some cases it may be appropriate to develop a model for a specific application.

- CMMS: Model can produce status reports and documents giving details or summaries of maintenance activities. The more sophisticated the package, the more analysis facilities are available.

- Value Engineering: Value techniques that are adopted during the detailed design stage and in some cases at the construction stage when completed design or elements of the design is made available for study.

- J10: This model is an IT project which when completed, will bring the department's project management and facilities management business applications together onto a single platform with a simple and efficient user interface. The platform and applications will leverage current technology to automate certain takes and improve usability for end users. This is the latest model that has been launched in year 2015.

\section{Methodology}

The processes involved in this study are summarized in Table 2. It illustrates three distinct levels of data collection, namely the first stage followed by the second stage and ended up with the third stage. The first stage was based on primary data collected from published books, research papers, seminar papers and journals while second phase used objective data from official sources of government experts. The third or final phase used subjective data from the actual replacement cost for Heat, Ventilation and Air Conditioning (HVAC) system in building.

Table 2: Methodology of Study

\begin{tabular}{|l|l|l|}
\hline Stage 1 & \multicolumn{2}{|c|}{} \\
\cline { 2 - 3 } & Stage 2 & Stage 3 \\
\cline { 2 - 3 } $\begin{array}{l}\text { Factors } \\
\text { Collection }\end{array}$ & $\begin{array}{l}\text { Validation of Factors and } \\
\text { Establish Relationship }\end{array}$ & Development of Actual Replacement \\
\hline
\end{tabular}




\begin{tabular}{|l|l|}
\hline CDM Factors & \\
RC Factors & \\
Asset Modeling & Based on Actual Data from \\
Existing practice & Interviews of Government Experts \\
Policy & (Objective Data) \\
Issues & \\
(Primary Data) & \\
\hline
\end{tabular}

The first stage concentrated on literature review on cost decision making factors and replacement cost factors that related to study. The first stage was based on primary data collected from published books, research papers, seminar papers and journals. The objective of the first stage is to identify independent variables that have significant relationship with the replacement cost, to evaluate current level of replacement cost, to established relationship between replacement cost and sets of independent variables and to determine the relative importance of each independent variable.

The second stage was conducted upon completion of the first stage with the following objectives to validate factors in stage 1 and to establish relationship between cost decision making and replacement cost. Validating a factor is a process that starts with the researcher, who then seeks validation among experts. The interviews conducted with the questionnaire survey consisted of variables thought to have effects on project's replacement cost to obtain detailed investigation information of the building replacement during their life cycle. The study adopted closed and open interviews in order to tap as
Actual Replacement of HVAC System of Building (Subjective Data)

much as possible information form parties interviewed. In this study, 11 personnel experts in the government office have been interviewed. The results of the interview data are presented in the Table 3. The third or final stage was based subjective data on pilot projects of development of replacement cost modelling for Heat, Ventilation and Air Conditioning (HVAC) system in buildings. The objectives of the third stage were to investigate to what extent the factors identified in the earlier phases had affected projects selected under the pilot studies, to identify other factors that could contribute to the replacement cost in project selected under the pilot studies. The pilot studies adopted closed and open interviews in order to tap as much as possible information from parties interviewed. All parties involved, including personnel on sites, were interviewed in order to acquire a more comprehensive view. On the other hand, subjective data can be considered as equally important and useful as the respondents possess extensive working experience and the information provided by them can be regarded as sufficiently reliable. The author considered research that uses both objective and subjective data is more comprehensive and conclusive.

Table 3: Research Data

\begin{tabular}{|c|c|c|c|c|c|c|c|c|c|c|}
\hline \multirow[b]{2}{*}{ No } & \multirow[b]{2}{*}{ Name } & \multirow[b]{2}{*}{ Designation } & \multicolumn{7}{|c|}{ Questionnaires } & \multirow[b]{2}{*}{ Note } \\
\hline & & & $\begin{array}{l}\text { 1.Existing } \\
\text { Guideline }\end{array}$ & $\begin{array}{l}\text { 2.Information } \\
\text { syst. }\end{array}$ & 3.Justification & 4.Improvement & $\begin{array}{l}\text { 5.Implementatio } \\
n \text { of LCC }\end{array}$ & Retrofit & Rebuild & \\
\hline 1 & Expert 1 & $\begin{array}{c}\text { KETUA } \\
\text { PENOLONG } \\
\text { PENGARAH } \\
\text { KANAN (ASSET) }\end{array}$ & BCA & Don't have & $\begin{array}{l}\text { Building } \\
\text { Condition }\end{array}$ & $\begin{array}{c}\text { Competenc } \\
y\end{array}$ & pilot project & & $x$ & \\
\hline 2 & Expert 2 & $\begin{array}{l}\text { TIMBALAN } \\
\text { PENGARAH JKR } \\
\text { PAHANG }\end{array}$ & LCC & Don't have & Age & Fund & very low & $x$ & & \\
\hline 3 & Expert 3 & $\begin{array}{l}\text { PENGARAH JKR } \\
\text { PAHANG }\end{array}$ & $\begin{array}{c}\text { Value } \\
\text { Engineeri } \\
\text { ng }\end{array}$ & Don't have & $\begin{array}{l}\text { Security } \\
\text { Risk }\end{array}$ & $\begin{array}{l}\text { Policy } \\
\text { safety }\end{array}$ & No implement & $x$ & & \\
\hline 4 & Expert 4 & $\begin{array}{l}\text { PENGARAH } \\
\text { JABATAN } \\
\text { KEJURUTERAAN } \\
\text { MAJLIS } \\
\text { PERBANDARAN } \\
\text { KUANTAN }\end{array}$ & $\begin{array}{l}\text { Don't } \\
\text { have }\end{array}$ & Don't have & $\begin{array}{l}\text { Use of } \\
\text { Building }\end{array}$ & $\begin{array}{l}\text { Computeriz } \\
\text { ed system }\end{array}$ & No implement & & $x$ & \\
\hline
\end{tabular}




\begin{tabular}{|c|c|c|c|c|c|c|c|c|c|}
\hline 5 & Expert 5 & $\begin{array}{l}\text { PENGARAH } \\
\text { (BSFB) }\end{array}$ & $\begin{array}{l}\text { Syor } \\
\text { Roboh }\end{array}$ & $\begin{array}{l}\text { Going } \\
\text { toward that }\end{array}$ & $\begin{array}{l}\text { Expected } \\
\text { Life }\end{array}$ & Database & No implement & & $\mathrm{x}$ \\
\hline 6 & Expert 6 & $\begin{array}{c}\text { PENGARAH } \\
\text { (ASSET } \\
\text { MANAGEMENT) }\end{array}$ & $\begin{array}{c}\text { Tatacara } \\
\text { Pengurus } \\
\text { an Aset } \\
2012\end{array}$ & My Spata & Safety & Database & need to build & $x$ & \\
\hline 7 & Expert 7 & $\begin{array}{c}\text { KETUA } \\
\text { PENOLONG } \\
\text { PENGARAH } \\
\text { KANAN (BFSB) }\end{array}$ & BPA & $\begin{array}{c}\text { My Spata \& } \\
\text { J10 }\end{array}$ & $\begin{array}{c}\text { Performanc } \\
\mathrm{e}\end{array}$ & $\begin{array}{c}\text { Guidelines } \\
\text { Improvemen } \\
\text { t }\end{array}$ & ongoing & $x$ & \\
\hline 8 & Expert 8 & $\begin{array}{c}\text { KETUA } \\
\text { PENOLONNG } \\
\text { PENGARAH } \\
\text { KANAN UKUR } \\
\text { BAHAN JKR } \\
\text { PAHANG }\end{array}$ & $\begin{array}{l}\text { Don't } \\
\text { have }\end{array}$ & Don't have & $\begin{array}{l}\text { Technical } \\
\text { problem }\end{array}$ & $\begin{array}{c}\text { Competenc } \\
y\end{array}$ & No implement & & $\mathrm{x}$ \\
\hline 9 & Expert 9 & $\begin{array}{l}\text { TIMBALAN } \\
\text { KETUA } \\
\text { PENGARAH } \\
\text { KERJARAYA } \\
\text { (SEKTOR } \\
\text { BANGUNAN) }\end{array}$ & BCA & My Spata2 & BCA & $\begin{array}{c}\text { Competenc } \\
y\end{array}$ & $\begin{array}{c}\text { not be } \\
\text { implemented }\end{array}$ & $x$ & \\
\hline 10 & Expert 10 & $\begin{array}{l}\text { PENGARAH } \\
\text { (CPAB) }\end{array}$ & BCA & Don't have & Safety & Database & No implement & $x$ & \\
\hline 11 & Expert 11 & $\begin{array}{c}\text { PENGARAH } \\
\text { KANAN (CPAB) }\end{array}$ & $\begin{array}{l}\text { Don't } \\
\text { have }\end{array}$ & Don't have & $\begin{array}{c}\text { Client } \\
\text { Request }\end{array}$ & $\begin{array}{c}\text { Decision } \\
\text { Making } \\
\text { Model }\end{array}$ & at early stage & $x$ & \\
\hline
\end{tabular}

\section{Question}

1. Any existing guideline to make decision in building replacement

2. Any existing software to make decision in building replacement

3. Critical justification of building replacement

4. Improvement of decision making process

5. Current implementation of LCC for government building

6. Which is cost efficiency, retrofit or rebuild?

\section{Discussion}

\subsection{Result and Analysis}

The aim of this phase is to identify the expert's responses on critical improvement and critical development in decision making of whether to retrofit or to rebuild the building. Based on the Table 3, 'Competency of Manager' and 'Information Database' are most important in improvement of decision making in building replacement, followed by 'Decision Making Model'. Their distribution are as follow; Competency (3), Information Database (3), Decision Making Model (2), Funding Availability (1), Computerized System(1) Policy Improvement(1).

Furthermore, Refer to Table 3, their contribution on theoretical framework are as follow: Human Factor (3), Technical Factor (2) and Organization Factor (6).
Organization factor are contribute $55 \%$ of the improvement requirement and Human Factor (27\%) and Technical Factor (18\%). Therefore, from this analysis, the 3 critical factors are need improvement are as follow which contributed $73 \%$ of improvement of decision making:

\section{Competency of Manager (27\%)}

2. Information Database (27\%)

\section{Decision Making Model (18\%)}

The study will focus on to improve the current policy that is being implementing by the government. This will include on how the Government make the analysis and make determination of the final decision 
on replacement of 'Heat, Ventilation and Air Conditioning' (HVAC) system. This study will present several factors, issues and figures. The elements of studies that will be put into consideration and to be analysed are the Replacement Cost (RC) factors and Cost Decision Making (CDM) factors as Figure 3 below. The study is meant to help the public sector which forms the biggest part of the buildings managing authorities in facing all the problems and difficulties. There are buildings with special design characteristic and with special function, unfortunately these specialty are normally costly to replace. These are normally due to deterioration and aging factor. Therefore it is urgent that a thorough study should be carried out to develop a guideline for the determination of replacement cost on these special buildings.

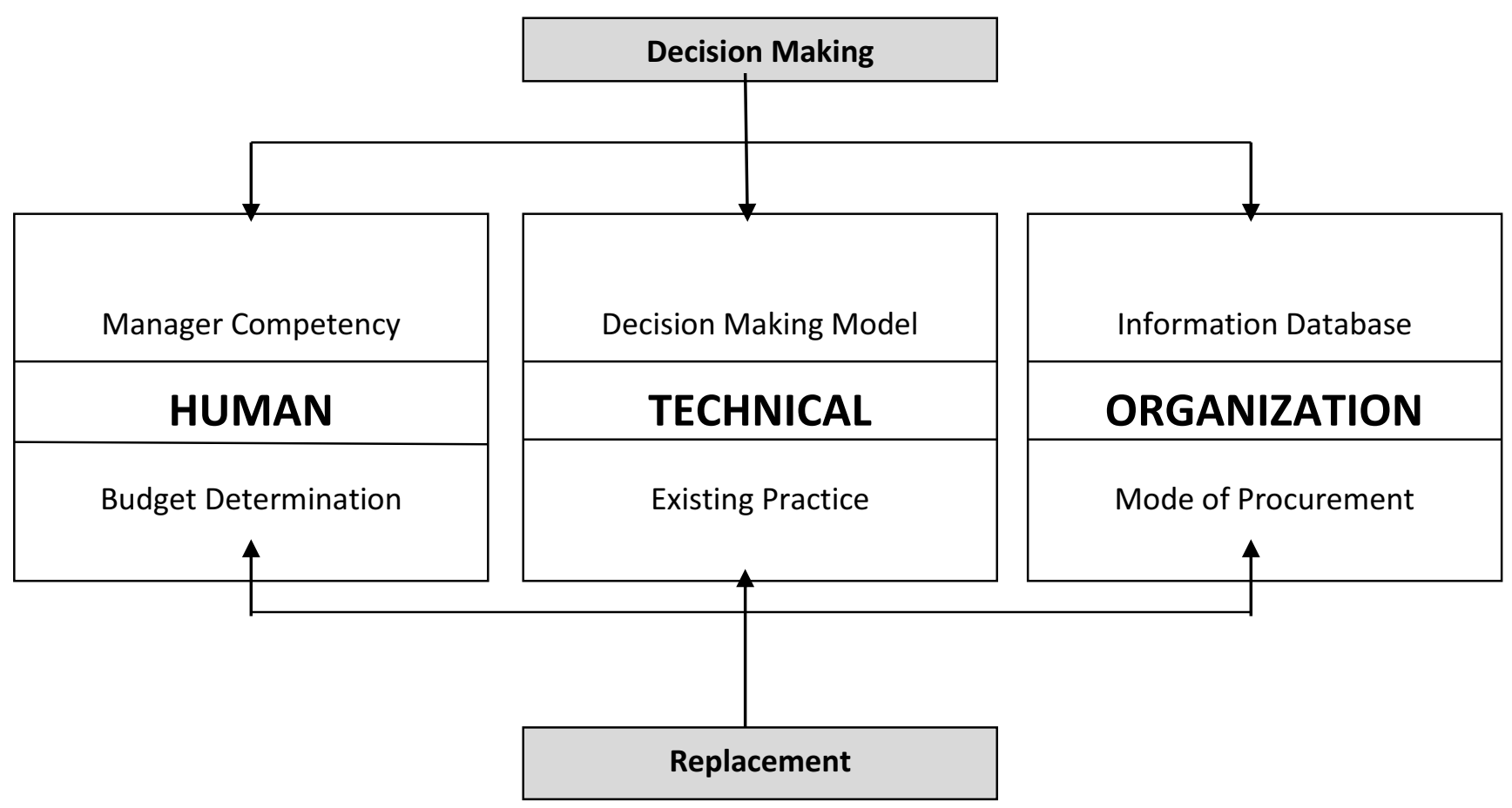

Figure 3: Relationship between Decision Making and Replacement

\subsection{Discussion}

The significance reason of this study is how to provide evidence in order to help the Federal Government to make a final decision on whether to restore or rebuild existing HVAC system. The figure shows the simple model to show the relationship between decision making and replacement cost. By using the model that will be proposed, it is hope that this evidences contributed to select optimum replacement cost for certain projects and directly helping in tendering process and ensuring the appropriate and transparency of job done.

\begin{tabular}{|c|c|}
\hline $\begin{array}{c}\text { COST DECISION } \\
\text { MAKING }\end{array}$ & REPLACEMENT COST \\
\hline Age of equipment & Compressor \\
Cost of repair & Condenser Coils \\
Warranty coverage & Evaporator Coils \\
Money saving & Air Filter \\
efficiency & Coil Fins \\
Future refrigerant & Contactor Relays \\
availability & Time Delay \\
Long term comfort & Compressor Power Pack \\
Long term savings & \\
Dependable comfort & \\
\hline
\end{tabular}

Figure 4: Replacement Cost Modeling For HVAC Asset 
Refer to Figure 4, this HVAC asset study will provide more details and relevant information of relationship between Cost Decision Making (CDM) and Replacement Cost (RC). Cost Decision Making consists of 3 factors such as human factor, technical factor and organization factor. Meanwhile, Replacement Cost factors related to modes of government procurement, budget determination and latest IT software application. This relationship study and discussion will contribute to the theoretical saving framework or saving policy that can save the government expenses. However, this theoretical framework only can be proof through actual analysis study on pilot projects of government procurement. Therefore, the author focus on HVAC System of building as pilot projects of this study.

Actually, the main objective of this study is to provide evidences to support a concept that restore of existing building are more benefit than replacement or rebuild to the new ones. The scope of the project and the key features of the asset of HVAC system of building are chiller, motor, compressor, cooling tower and piping. An air conditioner is any type of device that helps moderate temperature indoors. An air conditioner does not have to be cooling system; technically a heater is also an air conditioner, though most people seem to only consider air conditioners machines that lower the temperature to a user defined temperature. Making the decision to either repair your old building or replace with a new building is not easy. It's a decision government need to make every time. Government need to make a thoughtful, well informed and final decision making. Therefore, government need to developed all relevant performance and quality requirements such as age of equipment, cost of repair, warranty coverage, money saving efficiency, future refrigerant availability, long term comfort, long term savings and dependable comfort. Furthermore, part of asset that are subject to a costs analysis are compressor, condenser coils, evaporator coils, air filters, coil fins, contactor relays, time delay, compressor power pack and other mechanical parts. Optimum replacement cost that produced from this discussion hopefully can help government to make a justify decision.

\section{Conclusion}

From this analysis, we can conclude that this study is compulsory to be done by authorities in order to make sure the consistencies of decision making of government building replacement. Their life cycle management should be transparent and cost efficient, and decisions taken during the life cycle should be based on clear, justified and rational grounds. Therefore, the model is adapted to specific costs of such buildings towards transparency of their replacement.

From the questionnaire, we can conclude that the lack of cost analysis in decision making of building replacement as a weak point in the existing practices. Improvement of this process is compulsory to be done by authorities in order to make sure the transparency of decision making of government building replacement. Therefore, this study focuses to establish a simple, transparent and robust model that can be easily understood and used by the decision makers in practice.

Next analysis is which replacement is more benefit to the government in term of cost, retrofit or rebuild. Experts have to choose one and give their opinion on this question. Most the experts said the answer 'yes or no' are depend on the purpose of function of the building and specialty of the building. As for example, the heritage building should not be rebuild in order to maintain its original heritage criteria and history value. However, the experts gave their opinion are based on their experiences in dealing with this situation.

Based on the data Table 3, seven (7) experts said that retrofit is more benefit to the government meanwhile four (4) experts said that rebuild is more benefit to government expenses. Generally, about $64 \%$ of experts agreed that retrofit is more economically than rebuild to the new ones. Actually, the reason to choose retrofit are because of retrofit is more cheaper in term of cost, can increase competency of the manager, to maintain the heritage and valuable building, to minimize the residue material and to minimize impact to the environment. Otherwise, the reasons to choose rebuild are because of the business changes, to minimize security risk and fatalities, lack of database information and the expected life of the building.

Lastly, all the experts give the same opinion on the current implementation of Life Cycle Cost (LCC) for government building. There is no implementation of LCC in current practice for government building. Implementation of this process is compulsory to be done by authorities in order to achieve sustainable asset management. Finally and hopefully, the implementation of Life Cycle Costing (LCC) for government building will become a reality 


\section{References}

1. Hussien Ahmad Al Tarawneh, The Main Factors Beyond Decision Making, Islamic International University, Malaysia (2012)

2. Nor Azizah Mohammed Rum, Implementing Life Cycle Costing in Malaysia Construction Industry: A Review, Universiti Tun Hussien Onn Malaysia (2011)

3. N. Mohd Noor, Building Maintenance Budget Determination: An Exploration Study in the Malaysia Government Practice, University Technology MARA, Shah Alam, Malaysia (2011)

4. Kamarul Syahril Kamal, Pilot Survey On The Conservation of Historical Buildings in Malaysia, University Technology MARA, Malaysia (2008)

5. Matej Kusar, Selection of Efficient Refrofit Scenarios for Public Buildings, Faculty of Civil and Geodetic Engineering, University of Ljubljana, Slovenia (2013)

6. Carol C. Menassa, A Framework to Assess The Role of Stakeholders in

Sustainable Building Retrofit Decisions, Department of Civil and Environmental Engineering, University of Michigan, United States. (2013)

7. Azlan Shah Ali, Cost Decision Making in Building Maintenance practice in Malaysia. Faculty of Built Environment, University of Malaya, Malaysia (2009)

8. Ministry of Finance Malaysia, Government Procurement Division, Malaysia's Government Procurement Regime (2010)

9. International Organization for Standardization, ISO156-4:2014, Building Construction- Service Life Planning- Part 4: Service Life Planning Using Building Information Modelling.

10. UCL Public Policy, June 2014

11. Conference and Exhibition Pumping Best Practice for 2020, The International Centre, Telford (2015)

12. http://wwtonline.edie.net/features/repair-orreplace-make-informed-decisions

13. http://www.investorwords.com/4181/replace ment_cost.html

14. http://en.wikipedia.org/wiki/BREEAM

15. http://en.wikipedia.org/wiki/Leadership_in Energy_and_Environmental_Design

16. http://www.rics.org/my/knowledge/profesio nal-guidance/redbook
17. http://ec.europa.eu/environment/emas/es_lib rary/index_en.htm

18. Kerajaan Malaysia : Dasar Pengurusan Aset Kerajaan (2009)

19. Kerajaan Malasyia : Manual Pengurusan Aset Menyeluruh (2009)

20. The Ingeniur Magazine Volume 45 (2010) 